\title{
The Migration Archipelago: Social Navigation and Migrant Agency
}

Prof. Anna Triandafyllidou, European University Institute, Global Governance Programme

Anna.triandafyllidou@eui.eu

Post-print version dated 30 July 2018.

\begin{abstract}
This paper is inscribed into a new line of scholarly work seeking to cast light to the ways in which migrants convert their motivations into action within a policy framework that is characterised by many restrictions and limited opportunities to move. Drawing on recent fieldwork (2013-2014) on irregular migrants from Afghanistan, Albania, Georgia, Pakistan and the Ukraine, in Greece, we investigate how they perceive opportunities and navigate restrictions eventually crossing borders whether unlawfully (from unguarded border areas or with fake documentation) or legally (abusing the terms of their entry/stay). The paper adopts the notion of social navigation as a heuristics tool to conceptualise the social, temporal and spatial character of the migration journey, its nodal points, and the interaction of migrants with different actors and factors that shape their migration plans and explores different types of migrant agency (recuperation, resilience and resistance) developed during the navigation process.
\end{abstract}

Keywords: social navigation, migrant agency, irregular migration, asylum, southern Europe, governance 


\section{Introduction}

The ongoing migration pressures across the Mediterranean draw urgently our attention to the challenges that the EU is facing in its efforts to govern irregular migration and asylum. Policy responses focus overwhelmingly on the unauthorised character of the movement, and on how to limit or stop it, through multi-layered deterrence policies (Bloch and Chimienti 2011, Triandafyllidou and Dimitriadi 2014) which tend to neglect not only the complex drivers of migration but also the role of migrant agency. Recent scholarly work, by contrast, has paid increasing attention to the role of individual migrants, their families and networks and on the interaction between structural factors, relational forces and individual desires and aspirations. The former two are conceptualised as drivers of migration to emphasise their dynamic and interactive nature beyond the more traditional approach of push and pull factors (Van Hear, Bakewell and Long 2017) . The latter have been discussed using various terms like aspirations, desires, abilities and capabilities (see Carling and Schewel 2017 for a review). Efforts to conceptualise and operationalise the notion of migrant agency in irregular migration processes include the recent insightful work of Mainwaring (2016) and Squire (2017, also Strange et al. 2017). These recent studies seek to cast light on how migrants at highly constrained and vulnerable situations still seek to regain control and negotiate their situation, exercising agency. This paper builds on these recent findings focusing on different migrant populations facing different types of constraints in their effort to move. We look at how they perceive opportunities and navigate restrictions and discuss the different types of agency they develop in the process.

Borrowing the notion of social navigation (Vigh 2009) to conceptualise the migration process and to bring together the different actors and factors that interact with the migrants, and adopting Katz's (2004) framework which seeks to disaggregate the different forms of migrant agency, we explore how irregular migrants and asylum seekers develop forms of recuperation, resilience and resistance, in pursuing their migration project. This study joins a growing body of scholarly research that discusses the power of resistance of migrants and their capacity to enact change (Mezzadra 2013). We build on Vicki Squire's suggestion (2017) that we need to opt for alternative approaches beyond the structure-agency dilemma that privilege the importance of acts examining more closely whether acts of unauthorised migration change the very constraining context within which they take place, and generate "new scripts" (Squire 2017: 267).

Understanding better the dynamics of irregular migration is of crucial urgency for southern European countries, where irregularity has been a long standing feature of migratory flows in the post-1989 period and where governments have ostensibly insisted on deterrence policies seeking to appease their electorates, even if these have been shown not to work. This paper focuses on Greece as a destination country. Greece's transition to immigration at the early 1990s involved predominantly irregular movements, mostly from neighbouring Balkan countries. The undocumented character of the flows had to do with the lack of a policy for managing economic migration and a reluctance to recognise that immigration was a long term trend, in post 1989 Europe, not just a short-lived phenomenon. Greece became de facto a destination country in the early/mid 1990s while it regularised through three large "amnesty" programmes (in 1998, 2001 and 2005) hundreds of thousands of migrant workers (and their families) employed in agriculture, construction, tourism, small manufacturing, cleaning and domestic care. With shifting channels and routes of migration, and adjustments of smuggling operations to policy developments, Greece has witnessed flows increasing in the second half of the 2000s, through both its maritime borders and its north-eastern land border with Turkey. Violence and conflicts in the Middle East as well as wider areas of Africa and Asia have swelled migrant and asylum seeking flows towards Europe in general and towards Greece in particular since 2010, until the refugee emergency of 2015-2016 and the current reduced but continuous flux of asylum seekers and migrants. 
For the above reasons, Greece offers a suitable case for investigating how irregular migrants make decisions and execute their plans navigating restrictive policies, interacting with smuggling, kinship and other ethnic networks, in search of a better future. Building on earlier research conducted in other countries to show how migrants seek to 'use' policies, e.g. applying for asylum to obtain a temporary legal status (Bloch et al. 2011), go underground when other options are not available (Bloch ibid.), respond creatively to tighter border controls by passing as tourists (Chavez 2011), or indeed use their knowledge of other migrants' past experience or international law to insist on coastguard to rescue them (Mainwaring 2016), this study highlights how migrants develop different forms of agency in their 'navigation' process. The present study looks comparatively at five immigrant groups that have a strong presence among the irregular migration and asylum seeking flows in Greece, notably, Albanians, Georgians, Ukrainians, Afghans and Pakistanis. The fieldwork presented here was conducted in 2013-2014.

The paper starts by presenting the conceptual framework of the study elaborating on the notions of social navigation, nodal points in the navigation process, and migrant agency. Section three presents the comparative research design and methodology while section four turns to the actual analysis of the interviews. We explore migrants' motivations, the type of information they have and the agency they develop in setting off to navigate the migration field. We look at how migrants turn their decisions into actions mobilising resources and seeking to assess opportunities and risks. The paper concludes with a comparative discussion of the types of agency developed by migrants of different nationalities with a view to casting light to our understanding of migrant agency and irregular migration/asylum seeking dynamics today.

\section{A Conceptual Framework for Analysing Migrants' Agency}

Migration is a multi-dimensional (social, spatial, temporal) process which develops in non-linear ways, with several transit phases and places that can also involve moments of being 'suspended' both physically (because 'stuck' in a place) and legally (because in irregular status) (Oelgemoeller 2011). In other words, it is a 'fragmented' journey with different 'stops' and intermediate milestones where the journey can change nature and direction and where there can be also returns and new departures. During these phases, there is an interplay between the migrant's initial decision to migrate and her/his action of actually migrating, the conditions encountered while in transit and the related policies of both transit and destination countries, and the subsequent, or secondary decisions that the migrant takes. As Bivand Erdal and Oeppen (2017) point out such decisions are not necessarily voluntary just because the original decision was a voluntary one as the conditions in transit (e.g. abuse, violence, or by contrast finding a job and accommodation) may alter both the decision as such and its degree of voluntariness.

This paper adopts the notion of social navigation conceiving of the migration process as a transnational socio-temporal field, an 'archipelago'. The metaphor of the sea and of the archipelago is appropriate in conveying the fluidity and dynamism of the navigation. Indeed it borrows from the story of Ulysses, and from the effective character of migration as a journey of both spatial and temporal nature where many actors and many places are involved. Social navigation is a useful heuristic tool that allows us to position the different actors and factors within a single framework.

The navigation heuristics offers the framework within which to place the migrant and her/his individual agency, the other actors that interact with her/him, notably her/his family or household that may support or indeed obstruct her/his decision (see also Belloni 2016); the wider migration industry that provide their services to the irregular migrant to help her/him move (including smugglers, employment agencies, or employers); the enforcement and other control actors that seek to prevent her/him from moving; or indeed the third sector actors that may offer assistance during the journey or at destination. Thus we propose to conceptualise the migrant's agency as a specific capacity to navigate the migration field - the 'archipelago' between her/his origin and her/his intended destination. Indeed this is a special navigation capacity as unlike normal archipelagos this 
one is a moving target: the 'islands' notably the policies, their implementation, the stakeholders, the degrees of enforcement can change - it is as if an experienced captain prepares carefully a journey but the intermediate stops may even change position in the journey. Perhaps a little like Ulysses who, deprived of technological equipment, was unsure of whether he was going forward or moving cyclically and returning to places transited earlier.

The notion of 'navigation' includes both the initial stage where the migrant develops an aspiration to aspire to move, the capability to move, the resources mobilised, the journey and its different intermediary stops, the nodal points where the migrant may seek and mobilise resources to move further or the nodal points where the migrant may encounter Sirenes, and Cyclopes that will prevent her/him from moving further or will oblige her/him to take a different route or change the time of the journey. Such nodal points relate also to migration control and migration management policies. ${ }^{1}$ The notion of social navigation and the connection with the story of Ulysses and his journey fits contemporary migration understandings as these are not simply about where one wants to go and what one wants to achieve but also about who one wants to become (Collins 2017, Bal 2014), like Ulysses.

A crucial step in setting out from one's port to navigate the migration archipelago is gathering information about the destination and the opportunities it offers to satisfy the migrant's needs and wishes as well as to how to organise the journey. This is what Kahneman and Thaler (2006) call the anchoring of the decision to turn into action: migrants first evaluate the prospects that await them at destination and then they evaluate the hurdles to overcome in emigratingn. This process involves several stages of forming a preference to migrate; making plans; making preparations; moving; moving further as the movement is not linear from origin to destination. Considering these different stages from decision to action, it is important to note that migrants operate within contexts of bounded rationality. They do not simply make mathematical calculations about costs and expected earnings. They are influenced by their own desires to stay or leave, and in function of those constrain the information they receive and the choices they consider as possible courses of action (Galotti 2007, cit. in Koikkalainen and Kyle 2016). They thus tend to be selective in remembering past experiences (of their own or of others) and are also selective in the ways they consider their possible options (Koikkalainen and Kyle 2016). Examples of this positive asymmetry in socio-cognitive processing can be found in Townsend and Oomen (2015) who point out that many migrants disregard information about high levels of risk in their journey believing this will not happen to them and rather focus on the positive stories that they have heard of. As HernandezCarretero (2017) argues in her study of Senegalese emigration to Spain and return migration to Senegal, hope-filled uncertainty is preferred to hopeless certainty.

Taking note of the bounded rationality and limited information context within which the migrants engage into their navigation we focus on the different types of agency that they develop, in interaction with the other actors and places within the navigation field. We define agency as one's capacity to shape one's life and exploit opportunities or indeed open up new possibilities for one's self and their family. Following Katz (2004: 242) we consider three types of agency: recuperation, i.e. the autonomous initiative of the individual that aims at solving her/his own problem and addressing her/his own situation without necessarily changing the overall context; resilience, which includes not only changing one's own situation but also attempting at reworking one's circumstances opening up new possibilities; and resistance which is an action that seeks to subvert and disrupt the conditions under which one finds oneself. While these different types of agency have been studied in relation to legal migrants and their capacity to negotiate their employment conditions and relations (Berntsen 2016) they are yet to be employed to make sense of the agency of irregular migrants. While Mainwaring's (2016) work is particularly useful in showing examples of resistance of irregular migrants and pointing to the negotiation capacity that even migrants in

\footnotetext{
${ }^{1}$ On the notion of nodal points see also (AUTHOR 1). As regards how policies may affect the plans of migration see Czaika and Haas (2013: 497) on different types of substitution of the migration plan.
} 
distress can show, our aim here is to illustrate different types of agency of irregular migrants paying attention to different contexts and situations.

This paper focuses on the three first phases of the social navigation of the migrant, notably on the moment of taking a decision, alone or with family or friends; anchoring these decisions into relevant information; and overcoming restrictions while also mitigating risks through mobilising available financial and social resources. Our focus is on these first three phases of their journey seeking to circumvent obstacles, ignore restrictive policy arrangements, rework them or indeed resist and defy them. We seek to relate the different forms of agency with different phases of the social navigation process.

\section{Case Study Selection and Methodology}

The empirical research presented here comes from a larger study on the governance of irregular migration in southern Europe and particularly in Greece [AUTHOR 1]. We have selected five countries of origin notably Albania, Georgia, the Ukraine, Afghanistan and Pakistan, because they have been among the most important source countries of both legal but also and mostly irregular migration to Greece. We cover five different populations with a view to gain insights into different situations and contexts beyond an excessive focus on the recent 'refugee emergency' and the dramatic crossing of the Mediterranean under life-threatening conditions.

Irregular migration from Albania, Georgia and the Ukraine to Greece is inscribed within the wider framework of economically motivated migrations of the post 1989 period from the former Communist countries to southern Europe. Migration flows from Albania, Georgia and Ukraine to countries in southern and western or central Europe have been sustained through the 1990s as a result of economic crisis and rampant unemployment or underemployment. The brief overview provided here concentrates on the period between the mid-2000s and the mid-2010s when the fieldwork was conducted. Indeed this period was characterised by economic growth and a fragile political stability in Albania which built closer links with the European Union and has been working on a path towards future membership. This path however was interrupted by the global financial crisis and the Eurozone crisis. Italy and Greece being the main economic partners as well as migration destinations for Albanians, the crisis in these two countries has had important repercussions for the Albanian economy and society. Approximately 140,000 Albanian citizens returned to the country, of which a vast majority were men returning from Greece (approximately $70 \%$ of all) in the period 2009-2013 as they had been unemployed for long periods (Gemi 2017).

Greece has been a primary destination country for Georgians, partly because of cultural and religious affinities (Christian Orthodox religion) and because of indirect ties forged by the presence of a large Greek ethnic population in Georgia during the Communist times. While Georgia has been on a path of growth and political and economic stabilisation during the first decade of the century, this path was interrupted by the war with Russia in 2008 which had important negative repercussions in the economy and has led to a new wave of emigration as well as to Georgians leaving abroad, attempting to apply for asylum because of the conflict in their country. The situation has stabilised in recent years and according to the National Statistical Office in Georgia the net migration rate was negative in 2012 and 2013 signalling that more people have been returning than leaving.

The case of the Ukraine might be seen as similar to Georgia as the Ukraine too was on a path of economic and political stabilisation and growth and had been forging (like Albania) closer links with the European Union, but this path was interrupted by the conflict in Eastern Ukraine in 2014 and the annexation of Crimea by Russia. These developments affected both the situation of Ukrainians abroad (returns of undocumented Ukrainians from EU countries were halted) and have contributed to further emigration trends. However Western Ukraine which is the main area of origin of migrants to Greece has been less affected by the conflict. 
In short these three countries of origin share a Communist past and painful political and economic transition to a free market economy and a liberal democracy. Both processes are still in evolution and have gone through ups and downs which have had important repercussions in terms of migration trends. What is probably most important for our study is that all three countries have experienced a crisis of some sort in the years preceding our fieldwork: in Albania this was an economic crisis related to the overall Eurozone and global financial crisis, in Georgia and the Ukraine the crisis was more political in nature (having to do with their pivotal role and difficult relation with both Russia and the EU), but obviously had negative consequences for economic growth and hence influenced emigration.

Pakistan and Afghanistan as countries of origin for migrants in Greece are inscribed in a completely different geopolitical and socio-economic context compared to Albania, Georgia and the Ukraine. Afghanistan has been one of the major source countries of refugees for the past 30 years, and has been tormented by war since the Soviet invasion in the 1980s. Afghans who were coming to Greece prior to 2015, were seeking international protection but were often not filing asylum claims (because they aimed to move to another EU country). Several had spent relatively long periods (often 10 years or more) as refugees in Iran and were re-migrating because their lives in Iran had become harsher (Dimitriadi 2013; 2017). Pakistan, on the other hand, is both a major refugee host country with huge camps hosting Afghani refugees along the Afghani-Pakistani land border, and an important source country of economic migrants, including many highly skilled or family-related migrants headed to the UK and the USA. Other Pakistanis, including those with lower skills, go to new European destinations including Greece. Pakistani migration is not new to Greece, as the first groups arrived in the 1970s (Tonchev 2007), but has been quite invisible until the 2000s when it grew in size becoming the fourth largest group of non-EU migrants in Greece after Albanians, Ukrainians and Georgians.

The two flows, from Afghanistan and from Pakistan, are distinct in that the Afghani migration is mainly motivated by a lack of security and the search of both protection and a future in a third country while Pakistani migration has mainly economic motivations. At the same time, the two cases are also similar in that Greece is a new destination country with whom previous ties were limited (if existent at all). For Afghans Greece is but a station in the journey to some other European country where they can obtain asylum and settle (Dimitriadi 2013). The same was true for Pakistanis who saw Greece as a stepping stone to another European country but often ended up staying as they found jobs in Greece's large informal labour market in the pre-2009 period (Lazarescu and Broersma 2010). In the post-2010 period Pakistanis were the nationality group that participated mostly in the voluntary return programmes organised by IOM and the Greek government - pushed by the lack of employment and the collapse of both the formal and informal economy in the country - while Afghans were seeking to move to Italy and/or other European countries through smuggling networks.

Each country case study developed in parallel, starting with a period of desk research and fieldwork in Greece, interviewing stakeholders (state authorities, civil society actors, experts), and collecting relevant policy documents. At a second phase semi-structured qualitative interviews were conducted with irregular migrants in Greece while a third phase included interviews with returned irregular migrants or with people who considered leaving but did not depart. Interviews were conducted in Albania and Georgia while in the other three countries alternative fieldwork strategies were chosen. As regards Pakistan and Afghanistan, interviews were conducted via Skype with people in the countries of origin and also in Istanbul where many Pakistani and Afghani migrants and asylum seekers are in transit awaiting for a smugglers' passage to Greece. In the case of the Ukraine, where war erupted during the planning of the fieldwork, the trip was eventually cancelled, but contacts were taken with local civil society organisations who conducted interviews and facilitated Skype contacts. Further interviews were conducted in all cases with people in detention or under voluntary return procedures with the IOM. 
This paper is based on the analysis of interviews with irregular migrants in Greece and at the countries of origin (Georgia, the Ukraine and Albania) or in transit (in Istanbul, Turkey for Pakistanis and Afghans. The names used are fictitious. The analysis of the interviews and other materials was guided by the notion of social navigation and the effort to understand how migrants developed their decisions and actions, navigating a complex and uncertain environment with many stakeholders and factors involved.

\section{Table 1: Interviews with Immigrants}

\begin{tabular}{|l|c|c|c|}
\hline $\begin{array}{l}\text { Case study } \backslash \text { no } \\
\text { of interviews }\end{array}$ & $\begin{array}{l}\text { Immigrants } \\
\text { interviewed in } \\
\text { country of } \\
\text { origin }\end{array}$ & $\begin{array}{l}\text { Immigrants } \\
\text { interviewed in } \\
\text { Greece }\end{array}$ & Total \\
\hline Albania & 30 & 57 & 87 \\
\hline Georgia & 19 & 30 & 49 \\
\hline Ukraine & 13 & 28 & 41 \\
\hline Afghanistan & 23 & 30 & 53 \\
\hline Pakistan & 10 & 30 & 40 \\
\hline Total & 95 & 175 & 270 \\
\hline
\end{tabular}

Source: Author's compilation.

The following sections focus on how migrants develop different forms of agency in setting off to migrate. Our focus is on the passage from planning to action and on the ways in which migrants circumnavigate the policy restrictions at three specific nodal points (notably starting the trip, entering the country, first arrival). These three nodal points are understood as part of a social navigation field that involves movement in space and time and interaction with important actors within the field notably the family/household, smugglers and other service providers, kinship and ethnic networks, and the related mobilisation of resources.

\section{From Hopeless Certainty to Hopeful Uncertainty}

"Why did I go there? The 1990s were difficult years in our country. First of all, we didn't receive a salary, I worked as a teacher and my husband was an engineer. We lived in the village at the time, my husband worked at the collective farm. The collective farm was ruined. After that there were only odd jobs. Salaries were often delayed; sometimes they didn't pay at all. Once they gave us tiles instead of money. What will we give our kids to eat? You have to find a truck, take those tiles, go to the market to sell it and only then you will get some money". (Lilla, Ukrainian woman, aged 46, lived in Greece between 2000 and 2009, interviewed in Lviv in fall 2014)

"Great need. At home none was working, not the husband, we have a boy, we have two grandchildren, our daughter in law, we decided that I go to Greece" (Irina, Georgian woman, aged 51, interviewed in Chiatura, Georgia, in May 2014)

"We were three friends from a village, at night we sat there for company and we spoke of going to Greece. We may have a better life, to gather some money, to build some houses, (..) 
to make better life. And we came." (Ismail, Pakistani man, aged 33, interviewed in Athens in February 2014)

Prospective migrants are pushed to emigrate by circumstances at home and the lack of hope, despite their efforts, that things could be fixed. In our study, the motivations for migration were overwhelmingly economic for all groups except for Afghans. The quotes in our interviews are similar and eloquent for Albanians, Ukrainians and Georgians. There were no jobs and when working their salaries were not paid (in Ukraine) or were too low (in Georgia). Our informants engaged in both recuperation and resilience strategies to meet basic family needs but this was not sufficient. While Lilla and her husband initially engaged in resilience strategies, such as accepting the bricks for payment and seeking to sell them on the local market, she eventually had to opt for recuperation; the family decided that Lilla had to migrate to Greece to earn a living as a domestic worker even if that was to take place unlawfully. Similar recuperation strategies of 'voting with their feet' are evident in the case of young male Pakistani informants, like Ismail, or middle aged Georgian women, like Irina, both quoted above.

The options available to Albanians were slightly different. While the motivation driving current irregular migration to Greece was and still is low income and underemployment in Albania, thanks to the visa liberalisation for periods of up to 90 days, Albanian migrants circulate between the two countries relatively freely. They work in seasonal jobs, mostly informally, and when work is finished they go back. A bus driver who works for a travel agency that connects Athens with several Albanian cities sketches the profile of these irregular migrants: "They come for work that almost lasts a season and want no stamp on the passport" (interviewed in Athens, summer 2014). One of these circular irregular migrants also explains:

"I have done the trip more than six times on foot... once I paid a 1,200 euro fine because I had exceeded my [legal] stay period in Greece. I did not pay. And now I cross the border like this, on foot. When I have no employment [here] I go back but generally there is work. Many Albanians come like this. They come because they need to work for five months and their passport only allows them for three" (Petros, Albanian man, aged 34, interviewed in Rhodes, summer 2014)

Indeed Albanians engage into forms of resilience by seeking to navigate the policy options available to them (notably the tourism or seasonal employment visa - which they may abuse and/or overstay). If this does not work they engage in acts of pure defiance even if this does not come across in the interviews as real resistance. They individually defy the regulations and border controls but do not argue for a collective change of the conditions (such as for instance for liberalisation of the seasonal employment schemes in terms of duration and employment sector).

The case of Afghan informants is particularly interesting as they navigate their basically null opportunities to migrate through strategies of resistance. Insecurity and the lack of a future in Afghanistan and in Iran are a strong push factor along with motivations for finding employment and sending the children to school:

"We had documents and children could attend school, at first. But then things became very difficult, the children grew and we had no money for University so we thought to come to Europe" (Yasmin, Afghan woman in her late 30s, interviewed in Greece).

While the strategy is still family-based and does not involve any sort of collective action Afghan informants coming from Iran appear to not simply aim for recuperation but somehow defy or resist the downgrading of their situation in Iran by leaving. Their leaving is presented as a refusal to accept the situation and an attempt to claim for a better life.

A striking feature in migrants' accounts of their plans is their apparent lack of consideration 
of the restrictive policies, the controls and the risks involved when seeking to move. This is particularly the case of the Albanian informants who speak clearly about having been arrested and expelled in the past or having had to pay a fine. However they are not discouraged. Our informants make use of the information available (anchoring thus the desire into an assessment of obstacles and opportunities) and seek to navigate both the risks and the restrictions. Setting off to navigate the migration field our informants mobilise different sources of information in order to select the best available course of action.

\subsection{Afghans and Pakistanis: Unlawful Crossing and the Role of the Smuggler}

Afghans and Pakistanis have general information about what happens in "Europe" as well as some more specific information coming from direct relatives (who often are those who funded the journey) as to employment opportunities (or the lack thereof). But the information remains quite generic about the opportunity of finding employment that would be well paid or at least paid much better than what they earnt at home and would allow them to plan ahead in their lives and achieve something.

For Pakistanis and Afghans, information about opportunities to migrate comes along with information about smugglers. The two are nearly inseparable:

"It was a friend of his who did this job, who brings persons to Greece. He spoke with him and as everyone else came, he entered Iran with a visa, from there Turkey. Everyone who comes here until Iran they have a visa. In Turkey they also give visa but in Turkey to get a visa wants more money and they do not get a visa, they are smuggled" (Nayettulah, Pakistani man, aged 28, interviewed in Athens in September 2014).

In line with McAuliffe's (2013) and Mainwaring's (2016) findings, our informants use available information to plan ahead. The smuggler ${ }^{2}$ emerges as a key figure that makes the navigation of the policy restrictions and the crossing of international borders possible. Given the difficulty, length and risks associated with the journey, this last occupies an important part of the narrative and the role of the smuggler in making the project happen becomes one of paramount importance (see also Triandafyllidou and Maroukis 2012). The smuggler is a crucial resource in the navigation. Finding the money to pay requires mobilising financial resources among the extended family. Most informants from Pakistan had to sell family property to cover the fees while in the case of Afghans, informants come from upper middle class families apparently: “... my family wealthy. They sent some money to my uncle" (Yunus, Afghan man, in his mid-20s, interviewed in Greece).

Finding the smuggler and organising the trip is a form of collective recuperation: the migrant and her/his extended family seek a collective solution to the lack of options for legal migration: they sell their assets or borrow money to enable the migration project of the young man and thus open up options for a better future for the whole family. The migrants are aware that smugglers are criminals although opinions of whether they can be trusted or not differ among our informants, but this does not trigger a reflection about migration control policies or the unlawful character of the whole project. To put it simply the migrant does not consider her/himself as a criminal, as a person violating the law. This is what Ruhs and Anderson (2010) also label "the law in the mind". The unlawful crossing is only part of the navigation process and the smuggler one of the actors with whom migrants interact in their navigation of the migration archipelago. Indeed this kind of deliberate not seeing the illegal nature of their actions suggests that migrants engage thus

\footnotetext{
${ }^{2}$ We do not go into further detail here on the role of specific agents within the smuggling industry as this has been covered extensively in recent literature such as Zhang et al. (2018) or Triandafyllidou and McAuliffe (2018).
} 
into a form of resilience too, at least rhetorically. By arguing that their project is legitimate even if not legal they propose new scripts and new onto-political ways of being (Squire 2017: 267).

\subsection{Georgians, Ukrainians and Albanians: Obtaining a Visa to Navigate Uncertainty}

Georgians and Ukrainians are aware that they need a travel/tourism visa that they can apply for at the Greek consulate. In many cases such visas have been issued through the normal, legal path to Georgians who were invited by relatives or friends already living in Greece. However, half of the Georgians interviewed used the services of a travel agent who acted as a go-between and had the visa issued, upon the payment of fees (part of which presumably went to the employees of the consulate). That was also the case among Ukrainians during the 1990s, when such travel agencies flourished. Today information diffusion has improved in the Ukraine as it is now available through the internet and through dedicate phone services providing information on requirements to emigrate abroad.

Alongside the issuing of visas directly through the consulate or with the mediation of travel agencies, Georgian informants who did not have enough money to pay for the mediation fees circumvented the obstacle and travelled with the help of travel agencies that organised trips for undocumented people crossing from Georgia to Turkey (no need for visa) and then onwards to Greece, either by bus (upon paying a fee to the local smugglers recommended by the initial "travel agency" contact in Georgia) or simply crossing the Greek Turkish land border on foot.

"I live in a small provincial town, I do not live in Tbilisi, I was studying here and then decided to go to Greece. I came here to do my visa and my documents to go to Greece legally [i.e. with a tourism visa]. But it so happened that they put me in the bus and I came unlawfully to the country, without realising it" (Maria, Georgian woman, aged 36, interviewed in Tbilisi in May 2014)

Thus while obtaining visas is an important nodal point in the migration process for both Georgians and Ukrainians, people from the two groups navigate this obstacle in different ways. Ukrainians pay some semi-legal intermediary who organises the issuing of travel visas for tourism while Georgians use a mixture of navigation strategies ranging from simply crossing undocumented, to having a "travel agency" organise the journey and the visa to indeed obtaining a legal tourism visa through invitation by relatives. Paraphrasing Van Hear (2014) our informants did not go as far as their money would take them but through the path that their money could buy. This points to an important actually qualification in Van Hear's interesting arguments about the role of class and of different types of capital (social, cultural, economic) that an individual can mobilise to support their journey. Such capital conditions not only where but also how one gets to a desired destination.

A crucial point is the role of the close contact, the relative who is already in Greece:

"Here [in Greece] my cousin was waiting for me. She came [to meet me] as she knew I was coming, so she paid, she had money, I did not" (Irina, Georgian woman, aged 46, interviewed in Athens in November 2013)

In both cases of Maria above and Irina here, our informants engage in recuperation; they apply for a tourism visa so as to leave lawfully while those who do not have access to a legal visa, seek to navigate around the obstacle with the help of a 'travel agent' and the support of relatives abroad who await for them at destination.

Albanians by contrast, who are better informed and have wider networks to mobilise and rather detailed information about opportunities and obstacles in going to Greece for employment seek to rework the options available to them by engaging into semi-formal circularity. A crucial 
element here is that many have lived in Greece in the past plus they are all able to travel in the Schengen area, without a tourism visa, since December 2010. Our informants are aware of both entry restrictions and the fact that their 90-day stay is normally for tourism or leisure purposes and does not allow to work but this does not seem to be relevant. A smuggler interviewed in Vlores in the summer of 2014, explains:

"In 2002 the number of people who wanted to leave for Italy was reduced. The reason was fear. What's more, things in the [Greek] embassy had become easier. They issued visas with a 4,000 euro bribe so they preferred to go there and have six-month or annual visas rather than go to Italy because it was risky to travel by sea. People were afraid of the tragedies that had occurred (...) From 2011 onwards they left with (their) passports because they need not stay just for three months, they send their passport to the borders in order to get it stamped"

The biometric passports and the visa facilitation have changed the nature of the flows:

"Younger people come now, who work in the fields or in construction, seasonally. I bring more people in spring or fall" (Smuggler, mid-50s, interviewed in Athens)

They need to work and they thus seek to circumvent the rules. One way of doing this is to simply cross the border on foot or as Ali, another informant notes through petty bribing of border guards:

"My brother lives in Ithaca [an Ionian island, western Greece]. He sends his passport with some money to be stamped at the border every three months" (Ali, young Albanian man, late 20s, interviewed in Athens).

The stronger networks that Albanians can mobilise allows them to develop resilience. Relatives who have preceded the prospective migrant, smugglers and prospective employers or border guards that are bribed to stamp passports or close an eye at border crossings come together in a wider network that makes the movement possible (Krissman 2005).

\section{Comparative Remarks}

This paper has focused on the motivation, decision and turning to action of irregular migrants from five different countries seeking to enter Greece. The paper has explored qualitatively how migrants navigate an uncertain environment on the basis of incomplete information, aware of the risks involved but also hopeful for the outcomes of their migration project. Comparing the five nationality groups, a common navigation field emerges within which migrants form their decisions and engage in specific actions, with the help of a variety of actors and networks (kinship, friends, smugglers, locals). In this process of navigating the transnational migration field, and taking decisions or changing one's course of action at specific 'nodal points', several differences emerge among the five groups which contribute to our knowledge on the agency developed by irregular migrants faced with different conditions and disposing of different resources, complementing both earlier (Bloch et al. 2011) and most recent (Mainwaring 2016) work on irregular migrants' agency.

For irregular migrants coming from south Asia, the journey is long, dangerous and costly and using the services of the smuggler is necessary. The prospective irregular migrant turns to relatives or friends to obtain information about "Europe" and about the smuggler to contact. A range of extended family networks are mobilised to obtain the information and thus anchor the decision and raise the necessary funds for the trip. The funds are crucial for the service that will be purchased and hence for mitigating uncertainty. Besides Greece is only a first step of a journey that should lead to a farther country. 
For Georgians and Ukrainians obtaining a visa (real or fake) is the main strategy for crossing the border. The process involves bogus travel agents or petty smugglers who organise the unlawful border crossing. Albanians do not need a visa to enter Greece but seek some intermediary who can arrange for their passport to be stamped as if they left the country and re-entered so that formally the terms of their 90-day stay are not violated.

Interestingly all informants make sense of their migration project as a need or wish (unemployment, insufficient income, insecurity, violence) that they must satisfy. The focus of their narrative is on how to manage things and get through. Our analysis of how the migrant intention turns into action highlights the capacity of the migrant not only to act but also to create new scripts that seek to overturn the dominant meaning of unauthorised migration. Circumventing or reworking the relevant policies, these migrants challenge the dominant migrant agency script between victims or villains (Squire 2017: 268; Anderson 2008), and open up new possibilities. The migrant develops different types of agency to navigate the restrictive migration field: recuperation (through seeking information, gathering money, buying the necessary services or papers), or resilience (actively seeking to change the situation of the entire family and to open up new possibilities, and more rarely through resistance (seeking to change the conditions under which one finds one's self). Instead actually of seeking to change the conditions of the migration what we find is acts of defiance, defying restrictions and controls, fines and sanctions.

Those who face higher hurdles like Afghans or Pakistanis because of the length of the journey, the many crossings, the higher resources mobilised, the higher uncertainty, appear to resort to resilience if not resistance. By contrast those in the middle risk-and-resources-required category, notably Georgians and Ukrainians, engage into recuperation seeking to find solutions to their individual problems and navigate the hurdles, while Albanians those who are closer to destination and probably have the higher resources and lesser risks are the only ones who are likely to engage into resistance. But actually what we find is not so much resistance, rather they engage in defiance: they ignore the restrictions and disrupt the rules, probably as an indirect way of trying to challenge and change them. In all cases a collective element of action is missing but this may not come as a surprise as the very irregular character of moving and staying restricts any possibility for collective action. This paper focuses on the journey and thus of course leaves out opportunities and actual cases of mobilisation of irregular migrants demanding recognition and political belonging (McNevin 2009).

The findings of this study suggest that irregular migrants seeking entry into a destination country tend to develop recuperation and resilience agency rather than resistance. They privilege acts that can change their own situation rather than transforming the overall conditions. However, these acts that change their own fate and circumstances produce new subjects and new scripts (Isin 2012). Changing one's own circumstances without seeking to subvert the system is also indirectly a political act that shapes the context even if it does not transform it.

Using the notion of social navigation and the heuristics of 'nodal points' - notably intermediate 'stops' in the journey where a decision is taken and the course of action takes one direction or another - we have identified the different types of agency that migrants in transit and upon entering the destination country exert. We thus develop a heuristic framework that can be applied in different case studies to compare different irregular migrant or asylum seeking populations. We seek to go beyond ethnographic accounts that highlight the richness of individual cases, with a view to providing for a wider research framework that would allow for developing a matrix of irregular migrant agency analysis and hence offer the possibility of comparing and metaanalysing the findings of other studies. This paper points to the building blocks of such a matrix that would distinguish between different types of acts: individual or collective, different types of agency: recuperation, resilience, or resistance), and would identify the relevant actors involved (migrant and family, kinship networks, smugglers, employment agencies, transport companies, employers, government authorities and enforcement/control agencies, non-governmental 
organisations). Naturally further research is necessary to investigate the relationship between different types of acts, different types of agency and the navigation context.

\section{References}

Anderson, B.

2008 “Illegal Immigrant: Victim or Villain?” COMPAS working paper series WP-08-64. University of Oxford.

Anderson B. and M. Ruhs

2010 "Guest Editorial: Researching Illegality and Labour Migration" Population, Space and Place 16(3): 175-179.

Bal, E.

2014 "Yearning for faraway places: The construction of migration desires among young and educated Bangladeshis in Dhaka" Identities 21(3): 275-289.

Belloni, M.

2016 "My Uncle cannot say "No" if I reach Libya': Unpacking the social dynamics of border-crossing among Eritreans heading to Europe", Human Geography, 9(2): 4856

Berntsen, L.

2016 "Reworking Labour Practices: on the agency of unroganized mobile migrant construction workers", Work, Employment and Society, DOI $10.177 / 0950017015617687$

Bloch, A. and Chimienti, M.

2011 "Irregular migration in a globalizing world", Ethnic and Racial Studies, 34, 8, 12711285.

Bloch, A. Sigona, N. and Zetter, R.

2011 "Migration routes and strategies of young undocumented migrants in England: a qualitative perspective", Ethnic and Racial Studies, 34(8): 1286-1302

Bivand Erdal, M. and Oeppen, C.

2017 "Forced to leave? The discursive and analytical significance of describing migration as forced or voluntary", Journal of Ethnic and Migration Studies, DOI 10.1080/1369183X.2017.1384149

Carling, J. and Collins, F.

2017 "Aspiration, desire and drivers of migration", Journal of Ethnic and Migration Studies, DOI 10.1080/1369183X.2017.1384134

Carling, J. and Schewel, K.

2017 "Revisiting aspiration and ability in international migration", Journal of Ethnic and Migration Studies, DOI 10.1080/1369183X.2017.1384146

Chavez, S.

2011 "Navigating the US Mexico border: the crossing strategies of undocumented workers

Collins, F. in Tijuana, Mexico", Ethnic and Racial Studies, 34(8): 1320-1337.

2017 "Desire as a theory for migration studies: temporality, assemblage and becoming in the narratives of migrants", Journal of Ethnic and Migration Studies, DOI 10.1080/1369183X.2017.1384147

Czaika, M. and H. De Haas.

2013 "The effectiveness of immigration policies" Popuplation and Development Review 39(3): 487-508 
Dimitriadi, A.

2013 Transit and Migration in Greece (Dielefsi kai Metanastefsi stin Ellada), Athens: Nisos, in Greek.

Dimitriadi, A.

2017 "In search of asylum: Afghan migrants in Greece", European Journal of Migration and Law, 19(1): 57-76.

Gemi, Eda

2017 “Albanian Migration in Greece: Understanding Irregularity in a Time of Crisis", European Journal of Migration and Law, 19(1): 12-33.

Hernández-Carretero, María

2017 "Hope and uncertainty in Senegalese migration to Spain: Taking chances on emigration but not upon return" In Nauja Kleist \& Dorte Thorsen (ed.), Hope and

Isin, E. uncertainty in contemporary African migration. London: Routledge: 113-133.

2012 Citizens without Frontiers, London: Bloomsbury.

Kahneman, D, Thaler R.H.

2006 "Utility maximization and experienced utility", The Journal of Economic Perspectives 20: 221-234.

Katz, C.

2004 Growing up Global: Economic Restructuring and Children's Everyday Lives, Minneapolis, MN: University of Minnesota Press.

Koikkalainen, S. and Kyle, D.

2016 "Imagining mobility: the prospective cognition question in migration research", Journal of Ethnic and Migration Studies, 42(5): 759-776.

Krissman, F.

2005 'Sin Coyote Ni Patrón: Why the 'Migrant Network' Fails to Explain International Migration" International Migration Review 39(1): 4-44.

Lazarescu, D. and F. Broersma.

2010 "New migratory paths. Pakistanis and Bangladeshis in Greece" in A. Triandafyllidou and T. Maroukis (eds.) Migration in $21^{\text {st }}$ Century Greece, Athens: Kritiki, in Greek.

MacAuliffe, M.

2013 Seeking the views of irregular migrants. Decision making, drivers, and migration journeys, Occasional Paper 5| 2013, Irregular Migration Research Programme, https://www.homeaffairs.gov.au/ReportsandPublications/Documents/research/views-

Mainwaring, C. irregular-migrant-decision-drivers-journey.pdf

2016 "Migrant agency: Negotiating borders and migration controls", Migration Studies, 4(3): 289-308.

Oelgemoeller, C.

2011 "'Transit'and 'Suspension': Migration Management of the Metamorphosis of Asylum-Seekers into 'illegal migrants"'”, 37(3): 407-424.

Ruhs, M. and B. Anderson.

2010 "Semi-compliance and Illegality in migrant labour markets: an analysis of migrants, employers and the state in the UK" Population, Space and Place 16(3): 195-211.

Tonchev, P.

2007 "Asian Migrants in Greece: Origin, Present and Perspectives" Institute of International Economic Relations, Athens. http://www.idec.gr/iier/new/asian_migrants_en.pdf Last accessed on 17 April 2018.

Townsend, J. and Oomen, C.

2015 Before the Boat. Understanding the Migrant Journey, MPI Europe, April 2015.

Strange, M. Squire, V. and Lundberg, A. 
2017 "Irregular migration struggles and active subjects of trans-border politics: New research strategies for interrogating the agency of the marginalised", Politics, 37(3): 243-253

Squire, $\mathrm{V}$.

2017 "Unauthorised migration beyond structure/agency? Acts, interventions, effects, Politics 37(3): 254-272.

Triandafyllidou, A. and Dimitriadi, A.

2014 "Deterrence and Protection in the EU's Migration Policy", 49(4): 146-163, The International Spectator, http://dx.doi.org/10.1080/03932729.2014.956280

Triandafyllidou, A. and M. Ambrosini.

2011 "Irregular migration control in Italy and Greece: strong fencing and weak gatekeeping strategies serving the labour market" European Journal of Migration and Law 13: 251-273.

Van Hear, N. Bakewell, O. and Long, K.

2017 "Push-pull plus: reconsidering the drivers of migration", Journal of Ethnic and Migration Studies, DOI 10.180/1369183X.2017.1384135

Van Hear, N

2014 "Reconsidering Migration and Class" International Migration Review 48(S1): S100S121.

Vigh, $\mathrm{H}$.

2009 "Motion squared. A second look at the concept of social navigation", Anthropological Theory, 9(4): 419-438

Zhang, Sh. Sanchez, G. E., Achilli, L.

2018 "Migrant Smuggling as a Collective Strategy and Insurance Policy: Views from the Margins" 676(1). Special Issue. 